\title{
TRANSNATIONAL METROPOLITAN DEVELOPMENT STRATEGIES AND GOVERNANCE IN A POST-SOCIALIST SETTING: THE CASE OF SZCZECIN
}

\author{
AlexANDER TÖLLE \\ German-Polish Research Institute of the European University in Frankfurt-upon-Oder, Germany, and Adam \\ Mickiewicz University in Poznań, Collegium Polonicum, Słubice, Poland
}

Manuscript received: February 9, 2014

Revised version: May 13, 2014

TöLLE A., 2014. Transnational metropolitan development strategies and governance in a post-socialist setting: The case of Szczecin. Quaestiones Geographicae 33(4), Bogucki Wydawnictwo Naukowe, Poznań, pp. 43-56, 3 tables, 4 figs. DOI 10.2478/quageo-2014-0048, ISSN 0137-477X.

\begin{abstract}
The integration of cities and their regions into transnational networks has become a key municipal strategy, with the creation of a metropolitan governance structure being seen in this context as a fundamental element. The Szczecin Metropolitan Area constitutes an example of meagre results in intercommunal cooperation in post-socialist East-Central Europe. This has its repercussions on the task of creating cross-border metropolitan governance structures including adjacent German counties, a task which, in turn, may help to overcome development barriers. This becomes apparent particularly in the process of defining joint development objectives as well as an image for the cross-border metropolitan region.
\end{abstract}

KEY WORDS: cross-border metropolitan governance, Polish-German border area, post-socialist cities, Szczecin, transnational development strategies

Alexander Tölle, German-Polish Research Institute, Collegium Polonicum in Stubice, ul. T. Kościuszki 1, 69-100 Stubice, Poland; email: atoelle@amu.edu.pl

\section{Introduction}

The building of transnational links has become an essential aspect of urban and regional development strategies in Europe. The processes of globalisation and European integration have eroded the function of the national states as "territorial containers" (van Houtum et al. 2005: 2), which had once determined development parameters within the boundaries of their respective spaces. Globalisation can be "conceptualized as a multilayered process of expanding and intensifying transnational networking" (Krätke et al. 2012: 2), and cities and their regions are seen as the nodes of those networks. In consequence, the degree of integration of an urban region into transnational networks can be interpreted as a decisive factor for its development, and thus this integration has become a pre-eminent objective of urban development policies. However, their definition and implementation requires the creation of structures not only across territorial borders, but also across the border between the public and the private sphere, and across administrative units and responsibilities. With traditional hierarchic government structures widely seen as being insufficient to achieve this, the concept of governance stands for networking at a local and a regional level by creating cooperation structures, notably between the political level, the administration, the business community, and civil society (Fürst 2007; Lackowska, Zimmermann 2010). 
Hence "political and economic changes support an openness of regional actors towards reciprocal problem solving, networking and cooperation" (Heeg et al. 2003: 142) since the resulting governance forms are seen as a means to overcome political gridlock situations. In essence, governance structures created under the leadership of local or regional self-government allow assembling all public and private partners that may have an interest in a given project, and taking decisions on the basis of open negotiations and arrangements rather than formal and hierarchical procedures.

A prime area of application for governance structures is the building of metropolitan regions - unavoidably comprising several autonomous territorial self-government units - and their linking to transnational networks. On the one hand, metropolitan cooperation is important for the functioning of the core city (or cities) as well as the communes surrounding it, in the sense of focusing public investment, combining strengths and balancing weaknesses in order to increase competitiveness in a setting in which development tasks and problems have long surpassed narrow administrative borders (Lackowska, Zimmermann 2010). Yet on the other hand, it is important for the metropolitan region as a whole to increase its visibility and socio-economic potential, and to become connected to other urban economic regions in order to foster development. From this perspective, the process of metropolitanisation means "the return to the idea of a citystate" (Parysek 2006: 34) connected with other urban regions across national borders. Beyond the issue of building intercommunal cooperation structures, innovative network or cluster policies intended to specialise a metropolitan area and give it a clear profile so as to increase its competitiveness, require the establishment of networks of public sector units, private companies, science and research institutions, and the broader business environment (Koschatzky 2001). Such structures may offer a connection to transnational networks hardly accessible to individual actors, and therefore to transnational markets as well as knowledge networks - which is why the creation of an innovative region has become a development strategy dominating urban strategic thinking, and this in turn constitutes a prime example of the transnationalisation of urban strategies. It is connected with the 'creative city' approach defining creative and knowledge-intensive economic activities as "crucial for future urban economic development" (Musterd, Murie 2010: 17). Those activities are carried out by 'talents' (i.e. creative people) who are the hotbed of innovative thinking resulting in new products and production methods. Such talents create - and at the same time require - an urban milieu characterised by a transnational, open and tolerant society and by culturally diverse places. Despite the criticism of this concept, it has become widely accepted by urban decision-makers and integrated in urban development strategies. In consequence, urban marketing and image-campaigning has become focused on presenting a transnationally linked multicultural, open and tolerant urban society.

Thus, one may conclude that the building of governance structures is a requirement, first, within an urban region for tackling challenges deriving from the impact of transnationalisation processes that surpass internal administrative and territorial boundaries. Secondly, it is a prerequisite for making this urban region more competitive by integrating it into transnational networks. Hence, metropolitan governance is of particular importance for the cities situated east of the former Iron Curtain that were not only deprived of local self-government structures under their centrally planned economic systems, but that also had few chances to develop contacts across the usually hermetically closed borders of the Eastern Bloc. Overcoming the marginality deriving from the 'latecomer' status (e.g. in the perspective of long-established urban networks in Western Europe) has been, and still is, of main concern to city municipalities in East-Central Europe. The building of governance structures here constitutes a particular challenge as it requires the existence of fairly stable local government structures and socio-economic relations, which in the post-socialist context had to be established first. This article will look at the problem of defining and implementing metropolitan development strategies through the special case of the west Polish city of Szczecin in West Pomeranian voivodeship. In this Baltic seaport, the transnational dimension does not only concern the said aspects, but - with part of its functional agglomeration including territories in the German federal 
states (Bundesländer) of Mecklenburg-Cispomerania (Mecklenburg-Vorpommern) and Brandenburg, the building of a metropolitan region has a transnational dimension in its own right. This potential, unique in the German-Polish context, has led to the initiative to create the Szczecin Cross-Border Metropolitan Region (in Polish, Transgraniczny Region Metropolitalny Szczecina; in German, Grenzüberschreitende Metropolregion Stettin). This study will look at the peculiarities (deriving from the said 'latecomer' status) becoming apparent in the structures to create development strategies for this region; it will also highlight the chances deriving from this unique cross-border challenge to overcome barriers typical of post-socialist urban and metropolitan development.

\section{Indistinct urban development parameters}

Until the end of the Second World War, the city of Szczecin (called Stettin in German) had no historic legacy as a border city. The city was founded in the mid-13th century in the course of the German eastward expansion into Slavic settlement areas. It was a member of the Hanseatic League and the residence city of the Dukes of Pomerania, remained the provincial capital under the 1630-1720 interval of Swedish rule, and then became the capital city of the Prussian province of Pomerania. However, the shift of the Polish-German border in 1945 meant that Szczecin became a Polish city whose boundaries were only some 12 kilometres away from the newly-drawn state border. In consequence, the city found itself in a peripheral location. First, this was the case from the perspective of Poland's new state territory, of which it constituted the north-eastern corner far from Warsaw and other Polish economic hubs. Secondly, the peripherality had also a regional dimension, as the city was cut off from the western - German - part of Pomerania (Cispomerania), and therefore was situated in the far-off western corner of its eastern part (once named Farther Pomerania in German, today West Pomerania in Polish). In addition, the port, which had owed much of its dynamic development to the closeness of the industrial hub of Berlin, became cut off from the German capital city. Szczecin could have developed into an important Polish port city in the following years, "its seemingly free contact with the world was, however, severely limited by the tight state borders and the Iron Curtain" (Mieszkowska 1996: 111). Indeed, until the fall of the Iron Curtain, the close proximity of the German border, or in other words the character of Szczecin as a border city, constituted anything but an asset to its development. Notwithstanding all rhetoric about the alleged steadfast friendship between socialist brother states, the border between Eastern Germany and the Polish People's Republic remained rather impermeable for four decades, except for a short visa-free travel interval in the 1970s.

In addition, there was a strong psychological momentum connected with the closeness of the border, which may best be described as the "psychosis of provisionality" (Musekamp 2010: 122). This expression is generally used to depict the feeling of temporality of the Polish people who settled after 1945 in the country's western territories that until then had been part of Germany. In the case of Szczecin, there was a particular aspect to this: the Oder-Neisse line as agreed in the Potsdam Treaty would have meant a division of Szczecin into a German and a Polish half (as in the case of seven other cities on the rivers Oder and Neisse), with the vast majority of the city area actually remaining German. The city's destiny in the first months after the end of the Second World War was unclear, with Polish and German city administrations being established and dissolved repeatedly by the Soviet authorities, and the latter's ultimate decision to make the whole city a part of Poland and to expel the German population received no formal backing from the western Allies. As a result of this historical episode, the feeling of uncertainty as to whether the border just a few kilometres west of the city limits was there to stay, was a particularly burdensome and lasting one here - indeed, well until the fall of the Iron Curtain and the following formal ultimate acceptance of this border by reunited Germany.

So after the fall of the Iron Curtain, both from the geographical and transport infrastructure perspective and from a psychological point of view, the city - situated $120 \mathrm{~km}$ from Berlin (by 
a pre-war motorway), yet $450 \mathrm{~km}$ from Warsaw (by country roads) - appeared to be somewhat distant from the rest of the country, while socio-economic links to the nearby German border area were poorly developed. This marginality was also reflected by the ambiguity of socio-economic figures and the deriving development prospects in the 1990s. Estimates of the future position of Szczecin against the background of the other Polish cities varied between rather positive (Węcławowicz 1996, Lijewski 1998) and rather negative (Markowski 1997). This depended mostly on how beneficial the closeness to the western border was seen by individual scholars, and what prospects were expected for the port and maritime industries.

In fact, the city's position seems to be somewhat ambiguous until today. Being among the ten biggest Polish cities in population terms, Szczecin has the second highest unemployment rate and one of the lowest GDP per capita in relation to the national average (Table 1). The Szczecin Shipyard may have been made competitive by a courageous privatisation strategy in the early 1990s and may have been a pillar of the local economy for nearly two decades; however, the company went bankrupt in 2009. The ports of Szczecin and Świnoujście can form one of the biggest harbour complexes in the Baltic Sea region and can be a major economic hub of the agglomeration, but since 2005 "an ongoing decrease in the amount of goods processed has been observed" (Raport... 2012: 77), and insufficiencies in the container-adapted port and transport infrastructure are serious development hindrances.
And while the recently opened container terminal built by the DB Port Szczecin company, a subsidiary of the German Railways corporation, can certainly be seen as a substantial improvement of the port's competitiveness, the sea-related industry sector is still predominantly characterised by stagnating or diminishing figures. The city may be a major student hub with five public and twelve private universities, nevertheless against student figures in other Polish academic centres "the distance in relation to Poznań, Cracow and Wrocław is great" (Raport... 2012: 157). In addition, the research sector is rather poorly related to both city institutions and the private production sector, which is why West Pomerania is "one of the three least innovative regions in Poland" (Raport... 2012: 82). Hence Szczecin is a typical example of a post-socialist urban municipality that puts an emphasis on innovation and creativity policies in its strategies as a means to overcome marginality, while having to admit that such strategies have yielded poor results so far. The Szczecin 2025 Development Strategy discloses a "low level of innovativeness of enterprises resulting in a trifling number of innovative products and a small proportion of such products in sale figures" (Strategia... 2011: 15). The reason is seen in two main barriers: first, too little investment money for research, and secondly, "a lack of cooperation and dialogue at various levels" (ibid.).

From a macro-regional perspective, West Pomerania with its capital of Szczecin and the adjacent German territories form a cross-border region suffering structural difficulties on both sides of the state border, which also remains a sharp

Table 1. Szczecin's key figures in the ranking of the ten Polish cities with the highest population figures.

\begin{tabular}{|l|c|c|c|c|c|c|c|c|}
\hline \multicolumn{1}{|c|}{ City } & $\begin{array}{c}\text { Population } \\
\text { in thous. }\end{array}$ & Rank & $\begin{array}{c}\text { Area in } \\
\mathrm{km}^{2}\end{array}$ & Rank & $\begin{array}{c}\text { Unemployment } \\
\text { rate }\end{array}$ & Rank & $\begin{array}{c}\text { GDP per capita against national } \\
\text { average (Poland = 100) }\end{array}$ & Rank \\
\hline Warsaw & $1,708.5$ & 1. & 517.2 & 1. & 4.8 & 2. & 295 & 1. \\
\hline Cracow & 758.5 & 2. & 326.9 & 2. & 6.0 & 5. & 155 & 3. \\
\hline Łódź & 725.1 & 3. & 293.3 & 4. & 12.3 & 10. & 124 & \\
\hline Wrocław & 631.2 & 4. & 292.8 & 5. & 5.7 & 4. & 154 & 8. \\
\hline Poznań & 553.6 & 5. & 261.9 & 7. & 4.2 & 1. & 200 & 5. \\
\hline Gdańsk & 460.5 & 6. & 262.0 & 6. & 6.7 & 6. & $135^{*}$ & 2. \\
\hline Szczecin & 409.6 & 7. & 300.6 & 3. & 10.6 & 9. & 129 & 6. \\
\hline Bydgoszcz & 363.0 & 8. & 176.0 & 8. & 8.7 & 7. & 124 & 7. \\
\hline Lublin & 348.6 & 9. & 147.5 & 10. & 10.0 & 8. & 111 & 8. \\
\hline Katowice & 309.3 & 10. & 164.6 & 9. & 5.4 & 3. & 155 & 10. \\
\hline
\end{tabular}

*Figure for the Tri-City of Gdańsk, Sopot and Gdynia.

Source: own compilation based on the Central Statistical Office (GUS) (population in 2011, area in 2011, unemployment rate in November 2013) and PwC 2011 (per capita GDP rates in 2008). 
Table 2. Key figures of the study regions (NUTS-2) in the EU perspective.

\begin{tabular}{|l|c|c|c|c|}
\hline \multicolumn{1}{|c|}{ Region } & $\begin{array}{c}\text { Deviation from } \\
\text { EU-28 unemploy- } \\
\text { ment rate in percent } \\
\text { points in 2012 }\end{array}$ & $\begin{array}{c}\text { GDP per capita in } \\
\text { PPS in \% of EU-28 } \\
\text { average in 2011 }\end{array}$ & $\begin{array}{c}\text { Primary net income } \\
\text { of households per } \\
\text { inhabitant in \% of } \\
\text { EU-28 average in } \\
2010\end{array}$ & $\begin{array}{c}\text { Population devel- } \\
\text { opment 2004-2013 } \\
\text { in \% }\end{array}$ \\
\hline West Pomerania & +0.4 & 55 & 36 & +1.5 \\
\hline Mecklenburg-Cispomerania & +0.3 & 84 & 101 & -6.0 \\
\hline Brandenburg & -2.2 & 88 & 116 & -3.2 \\
\hline Berlin & +0.1 & 113 & 114 & +4.6 \\
\hline Poland & -0.4 & 65 & 37 & +0.9 \\
\hline Germany & -5.0 & 123 & 146 & -2.4 \\
\hline EU-28 & 0.0 & 100 & 100 & +2.6 \\
\hline
\end{tabular}

Source: own compilation based on EUROSTAT.

socio-economic one (Table 2). While unemployment figures are only slightly above the European average on both sides (which means, however - particularly in the German case - significantly higher than in the respective national contexts), the figures of both gross domestic product per capita and the primary net income of households per inhabitant seem to reflect two different worlds in that they are far lower on the Polish than on the German side. Nevertheless, in both arenas the German federal states of Brandenburg and Mecklenburg-Cispomerania show a performance well below the German (and in case of the GDP also well below the European) average. On the other hand, with a modest increase in the population, demographic development is more favourable on the West Pomeranian side, while in particular Mecklenburg-Cispomerania is subject to dramatic demographic shrinking processes. This federal state is characterised by predominantly rural and tourist functions (the latter mainly along the Baltic coastline), as is the north-eastern part of Brandenburg.

The NUTS-2 regional perspective, however, conceals the significance of Szczecin in two other regional dimensions. First, the city constitutes the only major urban hub in the German-Polish border area. This makes it the only urban core of a cross-border Euroregion - none of the other three German-Polish Euroregions include cities with more than 130,000 inhabitants. Secondly, while the region may be structurally weak, the city and its agglomeration still form its dynamic socio-economic and cultural centre. On some ten percent of the West Pomeranian territory, there live more than two thirds of its population and nearly half of its economic entities are registered, and unemployment is well below the voivodeship's average (Table 3; on the delimitation of the Szczecin Metropolitan Area, see below). In addition, the German counties (Landkreise) adjacent to this urban area are characterised by socio-economic figures well below the average of their respective structurally weak federal states, the former Cispomeranian county of Uecker-Randow being a strong case in point (see Kinder et al. in this volume). For those areas, Szczecin has come to be seen as a potential growth pole (Maack et al. 2005) despite the existing sharp economic and prosperity gap between Germany and Poland in general.

When trying to put the socio-economic situation of Szczecin into perspective, both its development path and prospects still seem to be rather hard to describe. For instance, the shipbuilding sector and port economy as a key development

Table 3. Key statistical figures for the city of Szczecin, the Szczecin Metropolitan Area and West Pomeranian voivodeship in 2011.

\begin{tabular}{|l|c|c|c|}
\hline & City of Szczecin & Szczecin Metropolitan Area & West Pomerania \\
\hline Territory in $\mathrm{km}^{2}$ & 301 & 2,597 & 22,892 \\
\hline Population & 409,596 & 644,699 & $1,722,739$ \\
\hline $\begin{array}{l}\text { National economy entities entered in the REGON } \\
\text { register }\end{array}$ & 65,134 & 93,066 & 214,584 \\
\hline Unemployment rate & 6.4 & 6.9 & 9.7 \\
\hline
\end{tabular}

Source: own compilation based on the Central Statistical Office (GUS). 
pillar can be interpreted as a potential growth factor after successful privatisation and reorganisation, or as a declining sector that may put the future of the whole region at risk. Similarly, the situation concerning innovativeness, business activities, or the academic and research sector can be interpreted either as offering great potential or as having an alarmingly low level. In addition, any assessment of Szczecin and its agglomeration seems to depend upon whether it is made from a national, a voivodeship, a macro-regional or a cross-border regional perspective. The last can be identified as a clear feature distinguishing Szczecin from other Polish cities, yet again this location in a cross-border space can be seen as both a "main challenge and opportunity" (PwC 2011: 10). All these ambiguities are reflected in the local public assessment of Szczecin being something in between a "metropolitan European growth area" and a "village with a tramway" (Dutkowski 2006: 98). Undoubtedly, however, it is this border location that has given a special transnational momentum to urban development strategies, as will be shown in the following part.

\section{Approaches to metropolitan governance in the national context}

In Szczecin, as in other post-socialist cities during the 1990s, the definition and implementation of urban development strategies was not only influenced by the unclear socio-economic development prospects. In addition, this task needs to be seen in the context of these cities having to introduce local self-government under the conditions of a democratic market economy. As a result, problems were manifold: insufficient local planning and development tools, disputed competences between the local and the central state level, weak citizenship, unstable political party structures, and lack of know-how and experience at the level of urban decision makers. In consequence, cooperation at the level of urban agglomerations had not become an issue in Poland until the beginning of the new millennium. By then, however, both the generally uncontrolled suburbanisation process around larger Polish cities calling for multiple cooperation structures (Zimnicka 2005), and
EU spatial concepts increasingly emphasising the role of strong metropolitan areas in the context of achieving spatial cohesion and improving the competitiveness of the EU as a whole, had turned this topic into an important one. Unfortunately, the building of metropolitan structures in the Polish context has two unhelpful characteristics, of which the first is a notorious lack of support at the central government level. According to Polish planning legislation, metropolitan areas are to be defined in the National Spatial Management Conception, and for these areas special plans are to be prepared by a voivodeship's self-government. However, as the national level has failed to define any metropolitan areas so far, some voivodeships have delimited them on their own authority. In the case of West Pomeranian voivodeship, its 2010 Spatial Management Plan defines what is called a Szczecin Functional Area in which metropolitan cooperation structures should be developed. However, as it comprises only nine communes,

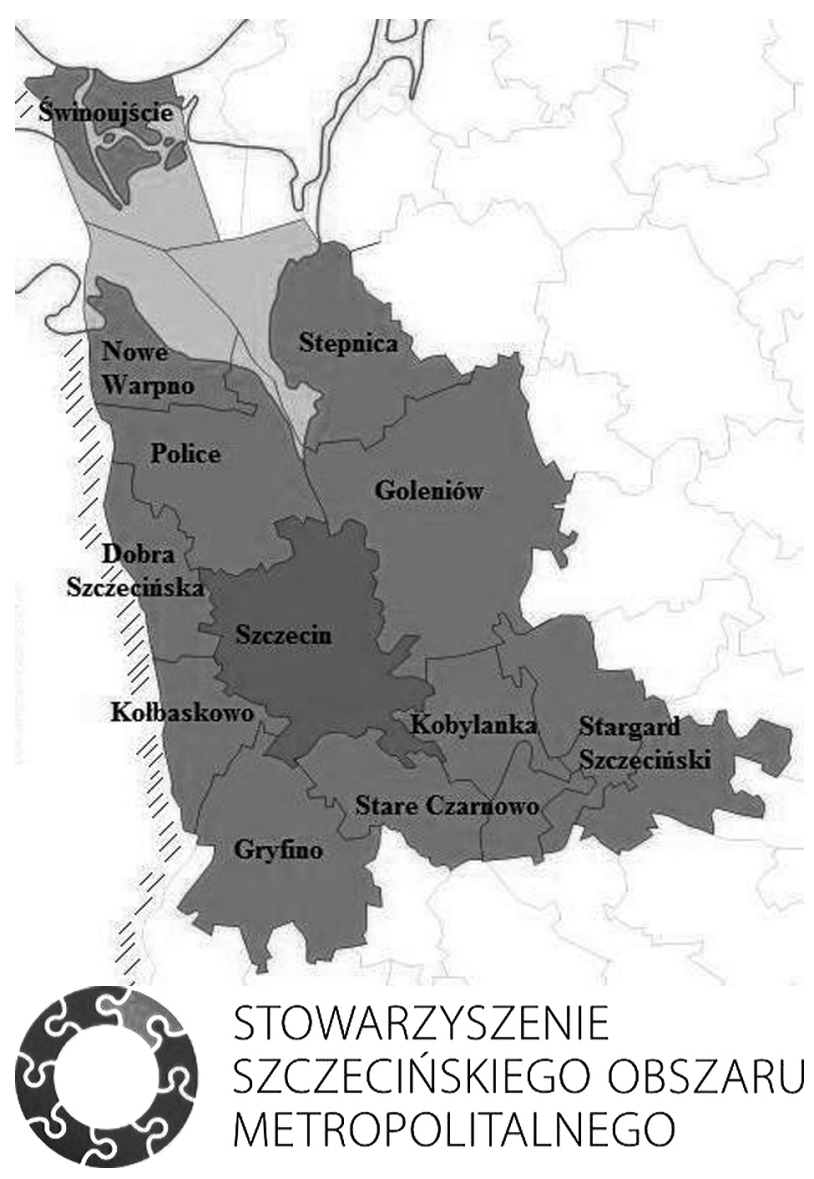

Fig. 1. Communes of the Szczecin Metropolitan Area Association in 2013

Source: www.som.szczecin.pl. 


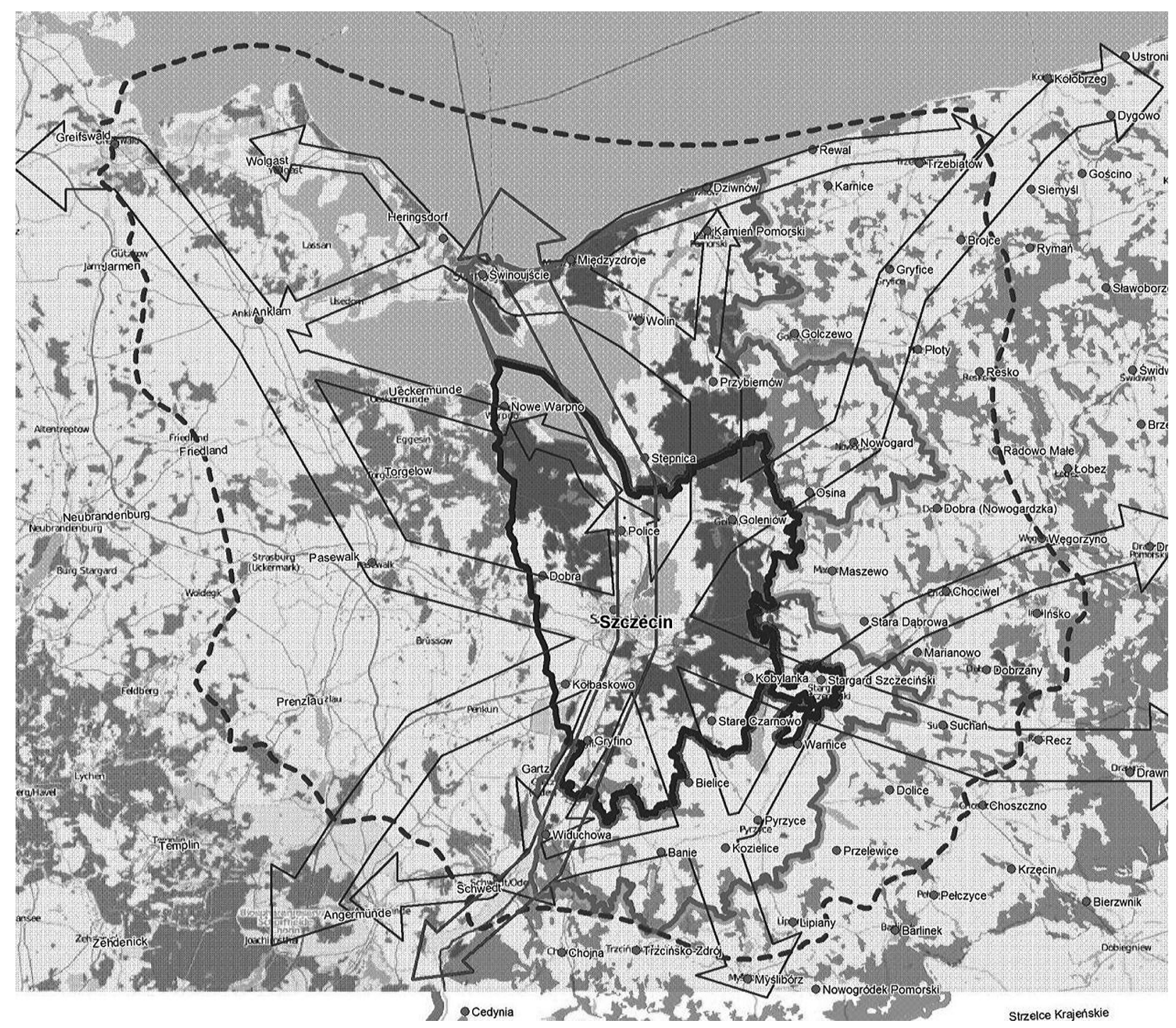

Fig. 2. Delimitation of the Szczecin Cross-Border Functional Region (dotted line). Dark grey line: Szczecin Functional Area; light grey line: Metropolitan Subregion. Source: Spatial Management Plan of West Pomeranian Voivodeship (2010: 161).

its territory is rather small despite being complemented by a so-called Metropolitan Subregion of another 16 communes (Fig. 2). In addition, Polish legislation has not provided for any metropolitan governance structures. In 2007, a far-reaching draft act on metropolitan areas designated 12 metropolitan groupings - formed by communes and poviats (powiaty, or counties) - that were to be responsible for spatial planning and transport infrastructure on their territory, with the possibility of being assigned further tasks by their territorial self-government units (Kaczmarek 2008). However, after long and heated political and public debates this act has never been passed in the parliament.
The second unfortunate characteristic of the Polish metropolitan dimension is an atmosphere of rivalry between municipalities (Lackowska, Zimmermann 2010), which is also apparent in the case of the Szczecin agglomeration. In 2006, a partnership agreement to create the Szczecin Metropolitan Area was signed by 13 communes, including the city of Szczecin, as well as three poviats and the self-government of West Pomeranian voivodeship. However, the Szczecin Metropolitan Area Association founded in 2009 currently consists of 13 communes (including Szczecin) and the West Pomeranian self-government (Fig. 1), but only one poviat. In any case, the Association undoubtedly does not represent all communes and poviats that can be seen as 
constituting the metropolitan area in functional terms, not even under the somewhat narrow delimitation given in the voivodeship's Spatial Management Plan. And the municipality of Świnoujście can stand here as an example of a lack of continuous communal commitment. This seaside resort and port city of some 40,000 inhabitants is undoubtedly closely connected with Szczecin in functional terms, not least because the ports of both cities form one harbour complex and are run by one joint seaport authority - no obvious thing in Poland, as the example of the two competing port authorities in Gdańsk and Gdynia shows. Yet this spirit of joining forces to increase competitiveness has extended to other fields only in limited terms. After the Świnoujście municipality could not resolve to sign the 2006 metropolitan partnership agreement, in 2009 it nevertheless became a founding member of the Szczecin Metropolitan Area Association - only to leave it shortly afterwards. However, in 2013 the city became a member again. The reason behind this behaviour can be explained by doubts concerning tangible benefits of cooperation on behalf of the Świnoujście municipality. This as such is understandable, yet it also shows a certain lack of understanding for the existing pressure deriving precisely from transnationalisation processes to cooperate in supra-local structures.

The Szczecin Metropolitan Area Association itself is a platform created to support joint activities helping to build this area, in particular in the fields of spatial planning, infrastructure development, environmental protection, solid waste management, economic and tourist development, marketing, culture, sport and leisure. Joint projects include preparatory work for a bicycle lane system, an improved efficiency of public services, and an increased attractiveness for tourists. A key venture is the preparation of a fast metropolitan railway system for the agglomeration, for which a feasibility study is currently being prepared. In total, it appears that some five years after its creation the Szczecin Metropolitan Area is still in a building-up stage. Governance structures including local authorities and - in specific projects some other partners may have been created, yet efforts to involve all local and supra-local territorial units forming the functional metropolitan region have not succeeded, and joint metropolitan activities of those that participate have a rather limited dimension. In that the Szczecin agglomeration mirrors a situation quite typical also of other Polish agglomerations (see Czepczyński in this volume on the Gdańsk Metropolitan Area and Lackowska, Zimmermann 2010 on the agglomerations of Wrocław and Warsaw), while so far only the Poznań Metropolitan Area (Kaczmarek, Mikuła 2010) and the Silesian Metropolis (Lackowska, Zimmermann 2010) have been able to show a record of metropolitan cooperation.

\section{Approaches to metropolitan governance in the cross-border context}

But in terms of the unique objective to create cross-border metropolitan structures, the Szczecin Metropolitan Area could well be seen as a typical example of half-backed metropolitan cooperation in a post-socialist context. Yet the fostering of cross-border metropolitan development, not least by means of European funding, has been clearly named a prime objective by the Szczecin Metropolitan Area Association. On the one hand, the German borderlands have increasingly become functionally closer to Szczecin since the Polish accession to the EU. Due to cheaper real-estate prices, numerous rather well-educated, wealthy and young households from Szczecin have moved not only to the Polish suburban areas around the city, but also to the nearby border towns and villages on the German side - where they are more than welcome, as they help to significantly slow down or even halt shrinking processes there (see Kinder et al. in this volume). On the other hand, the Szczecin municipality has adopted the strategy of integrating its German hinterland into its metropolitan policies as a vital part of its transnational strategies. This decision was preceded for some time by a polarisation of opinions: either Szczecin would seek partnerships with other main European metropolitan regions (e.g. the Berlin, Hamburg, Oresund regions) in order to foster development, or it would seek to strengthen its role as a regional centre and therefore remain rather unimportant from a European perspective. Yet "quite to the contrary, it is to be expected that the creation of strong ur- 
ban-regional cooperation structures is a prerequisite for becoming attractive in the global competition of regions" (Maack et al. 2005: 199). In consequence of this strategic approach, the city has defined a clear priority, viz. to develop its cross-border metropolitan region as the basis for its connectivity to transnational networks, and in general for "the strengthening and appropriate exploitation of the predisposition to fulfil the role of a transnational centre" (Kiernożycka-Sobejko 2011: 97).

From the German perspective, such approaches are certainly welcome, as Szczecin has come to be seen as a potential growth pole for the peripheral border region situated far from German production and tourist centres. In Germany, eleven metropolitan regions (Metropolregionen) have been designated at the federal (i.e. national) level, but they are characterised by a broad variety of organisational and planning structures as no guidelines have been defined in this respect. None of these metropolitan regions is situated in Mecklenburg-Cispomerania (the only major urban centres here being the Baltic port city of Rostock with a population of some 200,000 and the state's capital, Schwerin, with fewer than 100,000 inhabitants), with only two westernmost counties being part of the Hamburg Metropolitan Region. In contrast, the Brandenburg counties of Uckermark and Barnim - seen as part of the Szczecin Cross-Border Functional Region (Fig. 2) - belong to the Metropolitan Region (also named the Capital Region) of Berlin and Brandenburg. However, the reason for this is no particular close functional connectivity of this area to Berlin, but the fact that the federal state city of Berlin and the federal state of Brandenburg have agreed to define themselves as one metropolitan region. The close cooperation in this metropolitan region concerns notably the field of spatial development, with a Joint Planning Division (Gemeinsame Landesplanungsabteilung) elaborating metropolitan studies and planning documents. An additional task is the implementation of joint major infrastructure and business development projects.

In the first period after the accession of Poland to the EU, "no substantial integration process" (Maack 2010: 54) was detectable in the Szczecin cross-border region, and commitment was low among German as well as Polish local and regional decision makers (ibid.). Then, however, not least in the context of the said final adoption of the idea of a cross-border metropolitan region by the municipality of Szczecin, in 2010 the first tangible steps were taken on the Polish side: West Pomeranian voivodeship, the Association of the Szczecin Metropolitan Area, the city of Świnoujście (at that time not a member of the Association), and the Association of the Polish communes in the Pomerania Euroregion agreed to jointly prepare a concept defining development priorities for the Polish part of the Szczecin Cross-Border Metropolitan Region. The venture was coordinated by the West Pomeranian Regional Office for Spatial Planning. This concept was to set the grounds for a joint development strategy with the German side, as agreed in 2011 with the Joint Planning Division of Berlin and Brandenburg as well as with the spatial planning authority (Landesentwicklungsabteilung) of Mecklenburg-Cispomerania. Finally, in 2012, key aspects of a joint guiding principle and a joint development concept were agreed on in a Letter of Intent.

Apart from general objectives, such as improving life quality and the region's internal and external accessibility, tackling challenges deriving from demographic change, protecting and developing environmental and cultural assets, or increasing flood protection, two main strategic targets can be detected. In economic terms, the Szczecin Cross-Border Metropolitan Region is to specialise in the fields of sophisticated urban transport systems and renewable energy for the latter, the declared aim is even to create a cross-border model region. This is to be sustained by strategic network building - in the said fields and other branches - between scientific, technological and manufacturing institutions, both within the Szczecin Cross-Border Metropolitan Region, and those from this region with partners in other metropolitan regions. The second strategic target concerns the strategic European positioning of the cross-border metropolitan region. In this context, the sea port is to become a growth factor for the economy of the whole metropolitan region, and close cooperation between the Szczecin Cross-Border Metropolitan Region and the Capital Region of Berlin-Brandenburg, integrating also West Pomerania and the federal 
state of Mecklenburg-Cispomerania, is to ensure a joint identification and strategic positioning of Szczecin and Berlin in Europe. Summing up, one can conclude that the process of building and developing the Szczecin Cross-Border Metropolitan Region has started, and that partners on both the Polish and the German side have expressed their commitment. However, what is striking in this context is the complete lack of reference to the Oder Partnership, a joint initiative of four Polish voivodeships and four federal states to create a macro cooperation area.

\section{Elements of building a cross-border metropolitan region}

As a region stretching across the borders of two national states and three regional territorial units (not counting the numerous communal ones), the Szczecin Cross-Border Metropolitan Region is a superb example of the "increasing dissolution of the former congruence of regions (qua social practices) with territories (qua spatial units of political power and legal provision)" (Weichhart 2005: 94). This leads to the challenge of organising the process of cross-border metropolitan cooperation across administrative and state borders. The idea to constitute a joint "Working Group for the Szczecin German-Polish Central Region" (Maack et al. 2005: 21) or some similar body may have been promoted since Poland's EU accession, yet never implemented. Instead, the definition of development objectives and strategies has shifted to the level of administrative cross-border spatial planning. This is accompanied by the municipality of Szczecin defining a strategy for marketing its city - and possibly later the region - as a transnational place. Hence these two elements - the definition of transnational marketing and development strategies - are to be seen as the cornerstones building the Szczecin Cross-Border Metropolitan Region.

\section{Defining transnational marketing strategies}

The process of defining a city brand for Szczecin, started in 2007, can be seen as closing the phase of a lack of commitment of the Szczecin municipality to build a cross-border metropolitan region (Maack 2010). The resulting Szczecin Floating Garden 2050 Project is to communicate the vision of Szczecin as a city that is open, transborder, innovative, visionary, multicultural, and multilingual. The project logo contains the phonetic transcription of the city's name (Fig. 3), which is to represent the city's desire to communicate with people from different language backgrounds. The idea of a 'floating garden' derives from the fact that the city's territory includes many green areas, which - together with the presence of water - is perceived as its most distinguishing feature. So in marketing terms Szczecin is to feature as a metropolis that is at ease with humanity and nature, and thus a friendly place. The use of the term 'project' and the inclusion of a target year - 2050 - can be seen as an interesting approach to simulating a situation in which a certain state is to be achieved in a given time scale, as would be the case in the preparatory phase for instance of a major urban festival (the city's bid to be the Polish European Capital of Culture in 2016 failed in the first stage of the selection process) or sporting event (Szczecin was not included in the close circle of cities competing to become Polish host cities of the 2012 European soccer championship). The potential client of the Szczecin Floating Garden brand product was defined as being "open, creative, entrepreneurial, with a pioneering spirit" and as belonging to the "cando' category of people (Smalec, Wachowicz 2009: 111). This profile shows a clear connection with 'talents' in the creative cities' strategy approach.

The problem with defining an open, transnational marketing narrative for East-Central European post-socialist cities - certainly in the Polish

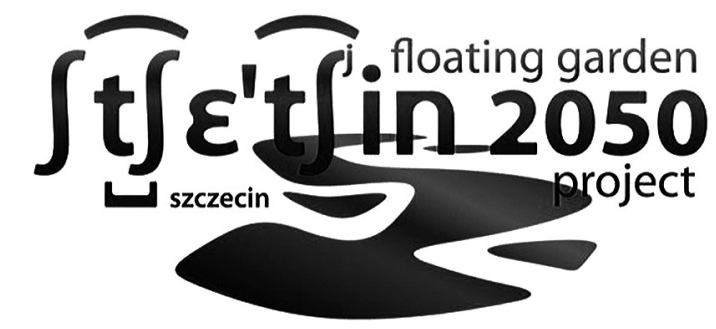

Fig. 3. Logo of the Szczecin Floating Garden 2050 Project (in the original coloured version in green and blue). Source: www.szczecin.eu. 
case, and Szczecin is no exception here - is their population structure, overwhelmingly homogeneous from a Western perspective. Those cities have a clear tendency to compensate for this lack of a transnational urban society, which is interpreted as a disadvantage against Western 'creative' cities, by defining a marketing narrative based on "a tradition of tolerance" (Tölle 2013a: 8) instead. By remarkable contrast, in the Szczecin Floating Garden Project any possible reference to some alleged 'tradition' is replaced by the highlighting of the transnational location of Szczecin as a city in the German-Polish cross-border region, and as a gateway to Scandinavia. Thus, in the marketing narrative, the lack of a multi-ethnic society at present is not compensated for by some tradition deriving from the past, but by a 'project' to build a transnational future. It is obvious that this project can be extended to a regional and a cross-border dimension. With the Szczecin Floating Garden Project already embraced by the Szczecin Metropolitan Area Association, its narrative could well be used to create the image of the cross-border metropolitan region. Yet while the definition of the marketing strategy - as can be expected - relied on communicative network structures integrating different groups and communities (Smalec, Wachowicz 2009), they hardly extended to a cross-border dimension. Yet both partners have agreed on an official logo in English (Fig. 4) that is to express the initiative of creating a joint metropolitan area, and that shows a clear connection with the theme of an urban landscape characterised by water and greenery.

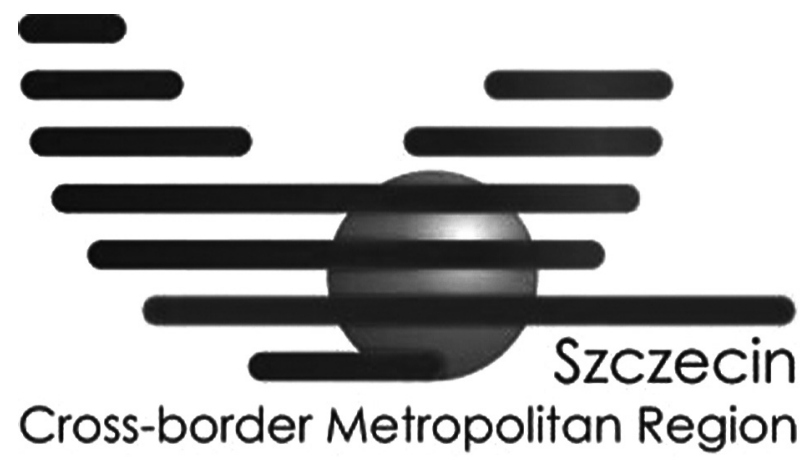

Fig. 4. Logo of the Szczecin Cross-Border Metropolitan Region (in the original coloured version with green and blue stripes and a red circle).

Source: http:/ /gl.berlin-brandenburg.de/europ-raumentwicklung/ metropolregion-stettin.html.

\section{Defining transnational development strategies}

The definition of a joint development strategy has become subject to a cross-border planning structure. On the Polish side, the West Pomeranian Regional Office for Spatial Planning has been charged with this task by the Associations of the Szczecin Metropolitan Area and of the Polish communes in the Pomerania Euroregion. Its German contact body is a private planning consultancy in Brandenburg working on behalf of the Joint Planning Division of Berlin and Brandenburg as well as of the spatial planning authority of Mecklenburg-Cispomerania. Also involved are the regional planning associations (Planungsverbände) responsible for spatial planning for territorial parts (in the German planning terminology, Planungsregionen, or "planning regions") of a federal state. Members of these regional planning associations are counties and their larger cities. Those are, on the Brandenburg side, the Regional Planning Association of Uckermark-Barnim (consisting of two counties, Uckermark and Barnim, as well as ten municipalities) and on the Mecklenburg-Cispomerania side, the two Regional Planning Associations of Cispomerania (consisting of two counties, Cispomerania-Greifswald and Cispomerania-Rügen, as well as nine municipalities), and the Mecklenburg Lake District (consisting of the county of the same name and its four biggest municipalities).

Hence the current setting is that the German and the Polish regional planning authorities prepare separate plans for their respective parts of the Szczecin Cross-Border Metropolitan Region, the coherence of those plans being achieved by cross-border coordination and communication. While this can be seen in general as a classical procedure of cross-border planning, one may doubt its efficiency in the context of building a cross-border region. The reason is fundamental differences in the understanding of and general approach to spatial planning in Poland and Germany (for more detail, see Tölle 2013b). The Polish planning system is oriented towards development control, and thus widely limited to the preparation of legally defined planning documents. In contrast, the German understanding of planning is much more that of an integrated pro- 
cess to actively develop a given territory, based on an established consensus on how to deal with conflicting uses and functions. In consequence, the German planning system is characterised by cooperative forms of preparation of legally defined as well as informal planning documents, letting them both influence spatial development to different degrees.

Perhaps of even greater importance for the issue of cooperation is the fact that the Polish planning system is characterised by a strictly hierarchical approach, with the participation of the broader public as well as public institutions or neighbouring local and regional self-government units being limited to writing notes on planning intentions or prepared draft plans. Between planning levels, the relevant provisions of a higher planning level are to be included in the plans of the lower level, while the influence on the preparation of higher-level planning documents again is reduced to writing assessments on draft plans. In practice, however, this strictly hierarchical planning structure is somewhat contradicted. When it comes to making administrative decisions on third-party interests such as granting or refusing planning permissions, Polish jurisdiction does not allow taking into consideration any planning provisions other than those adopted by a municipality in the form of a local by-law that is legally binding for the general public (i.e. in the form of a so-called local spatial management plan). In consequence, any planning provisions at the regional or metropolitan level, even if included in legally defined planning documents, has to be secured by a municipal by-law in order to have an impact on spatial development. This gives the commune a somewhat predominant position in the Polish planning system. The German system, however, has no tendency to mingle the planning hierarchy with predominance questions. The link between different planning levels is established on the basis of the so-called principle of countervailing influence (Gegenstromprinzip). This principle expresses the idea of adapting the spatial development of any single spatial territory to the requirements of the overall territory, and in turn of developing the overall territory in accordance with the situation and parameters of its individual parts. The institution of the regional planning association is a point in case here, as it has to consider provisions defined by the planning authority of a federal state for the whole of its territory, yet at the same time it contributes to the definition of those provisions. On their basis the regional planning association defines the planning and development objectives for its planning region, and institutionally integrates the municipal level.

The said differences may well result in problems concerning the later implementation of jointly defined development objectives. With the German institution of regional planning associations having no Polish equivalent, a decisive question is how far Polish communes are willing to accept joint planning objectives defined at a regional level. In contrast, a development concept for the German part of the Szczecin Metropolitan Region would be seen there as a basis for the definition of principles (Grundsätze) and objectives (Ziele) in the regional and federal-state spatial development programmes (Regionales/ Landesraumentwicklungsprogramm), which in turn would have an impact on the provisions in local planning documents ('principles' have to be considered by local planning authorities, 'objectives' are even binding for them). While on the Polish side the voivodeship planning authority can also decide to incorporate provisions deriving from the metropolitan development concept into its spatial management plan, the impact this would actually make on regional and local spatial management is somewhat less stringent. In consequence, the voivodeship planning authority would be well advised to carefully consult its planning resolutions with the communes, as in practice much depends upon their attitude and willingness to cooperate.

Thus, regional planning associations on the German side directly represent the poviat and municipal (of the region's major cities) levels, and indirectly - i.e. through the principle of countervailing influence - the federal state and the general municipal level. At the same time, they are institutions in charge of (metropolitan) regional planning. By contrast, the Szczecin Metropolitan Area Association represents the poviat and municipal levels (not all communes constituting a functional area), but has no planning competencies. The planning authority of the voivodeship, in turn, is in charge of (metropolitan) regional 
planning. So it formally does not represent the interests of communal self-government, which is in effect "the basic link in the Polish system of planning" (Parysek 2009: 40). This difference of representation and planning competence will have to be taken into account if any building of cross-border metropolitan governance structures is to be based - for the lack so far of any other approaches - on joint planning structures. Yet if the building of cross-border partnership structures indeed requires "trust, continuity and a shared view of problems" (Knippschild 2005: 179) in the first place, then a joint planning venture can still contribute to this - and perhaps have an impact on the wider political and administrative sphere.

\section{Conclusions}

Concerning integration into transnational networks, the Szczecin of today shows typical features of a post-socialist city. The building of a strong urban region (as a basis for any transnational urban strategies) by intercommunal cooperation has been only partly successful - while there exists a Szczecin Metropolitan Area Association, it does not represent all self-government units in the functional area and has a limited range of activities. Accordingly, the integration of other public and private partners in the sense of metropolitan governance is still in a setup state. A clear indicator is the low level of innovativeness in the city and region, despite this being a declared key strategic objective in recent years of both the city and the voivodeship. This setting makes it understandable why any scenario of building metropolitan governance structures and then integrating cross-border relations into them is not a viable option for building the Szczecin Cross-Border Metropolitan Region. In institutional terms, the lack of metropolitan governance structures is compensated for by the integration of the Association of the Polish Communes in the Pomerania Euroregion (yet not all of them are functionally connected with the agglomeration of Szczecin), which is an intercommunal cooperation platform. However, the approach involving the use of the Euroregion level is one-sided and thus inconsistent: the definition of development strategies for the cross-border metropolitan region has in effect not become a matter of Euroregional governance (whose structures would hardly be up to such a task - see Czernik 2010), but of cross-border spatial planning. This raises the issue of planning systems in post-socialist countries being rather geared towards development control, with strictly defined formal requirements concerning any impact of planning documents - perhaps in reaction to arbitrary acts by state administrations in socialist times. Metropolitan planning based on such an approach is hardly compatible with the understanding of the preparation and implementation of informal planning documents as a governance process integrating partners across territorial borders, of which the German planning system is a mature example. Yet, with the strategy to build a cross-border metropolitan region seen on both, the West Pomeranian and the Cispomeranian and north-east Brandenburg side as by far the most promising way to overcome marginality and connect to transnational urban and economic networks, it remains to be seen whether it will be possible to overcome the barriers resulting from the typical features of post-socialist city development and planning structures. In turn, the borderland location of Szczecin has evidently inspired the preparation of an unusual and promising marketing narrative. It may be in line with images built in other post-socialist cities in that it is geared towards the creation of an urban identity of openness and tolerance, yet in Szczecin the municipality seizes the opportunity to build this image on its current cross-border situation and the intention to exploit it further, rather than on any historical tradition. This may well help to create place identity for the whole of the cross-border metropolitan region. Finally, the borderland location of Szczecin perhaps exposes problems with defining development strategies for post-socialist cities. At the same time, however, this location is a potential that may well lead to overcoming some of those problems.

\section{References}

Czernik L., 2010. Cross-border aspect of Szczecin Metropolitan Area. Przestrzeń i Forma 13: 194-202.

Dutkowski M., 2006. Szczecin - "Metropolitanes europäisches Wachstumsgebiet" oder "Dorf mit Straßenbahn"? (Szczecin - "a metropolitan European growth area" or "a 
village with a tramway"?) In: Stöber G. (ed.), Deutschland und Polen als Ostseeanrainer. Hahnsche Buchhandlung, Hannover: 98-108.

Fürst D., 2007. Governance. Einblicke in die Diskussion (Governance. Insights into the discourse). Städte im Umbruch 4: 5-10.

Heeg S., Klagge B., Oßenbrügge J., 2003. Metropolitan cooperation in Europe: Theoretical issues and perspectives for urban networking. European Planning Studies 11 (2): 139-153.

van Houtum H., Kramsch O., Zierhofer W., 2005. B/ordering Space. Prologue. In: van Houtum H., Kramsch O., Zierhofer W. (eds), B/ordering Space. Ashgate, Aldershot \& Burlington: 1-13.

Kaczmarek T., 2008. Aglomeracja poznańska jako region badania i działania (The Poznań agglomeration as a research and action area). In: Kaczmarek T., Mizgajski A. (eds), Powiat poznański. Jakość przestrzeni i jakość życia. Bogucki Wydawnictwo Naukowe, Poznań: 15-36.

Kaczmarek T., Mikuła Ł., 2010. Poznańska ścieżka integracji metropolitalnej (The Poznań metropolitan integration path). In: Lutrzykowska R., Gawłowski R. (eds), Wyzwanie polskiej polityki miejskiej. Adam Marszałek, Torun: 168-187.

Kiernożycka-Sobejko A., 2011. Transgraniczny charakter Szczecina szansą jego rozwoju (The transboundary nature of Szczecin city is an opportunity for its development). Wspótczesne Problemy Ekonomiczne 3: 87-98.

Knippschild R., 2005. Potentials of cross-border cooperation for strategic urban development in border regions. Designing and evaluating informal cooperation processes. In: Giffinger R. (ed.), Competition between cities in Central Europe: Opportunities and risks of cooperation. ROAD, Bratislava: $173-183$

Koschatzky K., 2001. Networks in innovation research and innovation policy - an introduction. In: Koschatzky K., Kulicke M., Zenker A. (eds), Innovation networks: Concepts and challenges in the European perspective. Physica, Heidelberg \& New York: 3-23.

Krätke S., Wildner K., Lanz S., 2012. The transnationality of cities: Concepts, dimensions and research fields. An introduction. In: Krätke S., Wildner K., Lanz S. (eds), Transnationalism and urbanism. Routledge, New York \& Abingdon: 1-30.

Lackowska M., Zimmermann K., 2010. New forms of territorial governance in metropolitan regions? A Polish-German comparison. European Urban and Regional Studies 18(2): 156-169.

Lijewski T., 1998. Die ranghöchsten Zentren und die Wirtschaftsräume Polens (Poland's high-ranking centres and economic areas). In: Städtesysteme und Regionalentwicklungen in Mittel- und Osteuropa. Rußland, Ukraine, Polen. IfL, Leipzig: 167-196.

Maack K., 2010. Wachstumspol Stettin. Entwicklung der deutsch-polnischen Grenzregion. Aktualisierung der Studie "Wachstumspol Stettin und Auswirkungen auf die Entwicklung der deutsch-polnischen Grenzregion" (2004) (The Szczecin growth pole. The development of the German-Polish border region. Update of the study "The Szczecin growth pole and implications for the development of the
German-Polish border region" (2004)). Hans-BöcklerStiftung, Hamburg.

Maack K., Grundmann M., Kreft J., Lewandowska A., Voß E., 2005. Wachstumspol Stettin und Auswirkungen auf die Entwicklung der deutsch-polnischen Grenzregion (The Szczecin growth pole and implications for the development of the German-Polish border region). Edition der Hans-Böckler-Stiftung, Düsseldorf.

Markowski T., 1997. Major tendencies and structural problems of major Polish cities in the new economic context. DISP 33 (130): 40-46.

Mieszkowska K., 1996. City profile: Szczecin. Cities 13 (2): 109-116.

Musekamp J., 2010. Zwischen Stettin und Szczecin. Metamorphosen einer Stadt von 1945 bis 2005 (Between Stettin and Szczecin. Metamorphoses of a city from 1945 to 2005). Harrassowitz, Wiesbaden.

Musterd S., Murie A., 2010. The idea of the creative or knowledge-based city. In: Musterd S., Murie A. (eds), Making competitive cities. Wiley-Blackwell, Oxford: 17-32.

Parysek J.J., 2006. Processes affecting the development and transformation of towns in Central European states: The case of Poland. Quaestiones Geographicae 25: 29-36.

Parysek J.J., 2009. Urban development in Poland after 2003: Legal regulations and reality. Quaestiones Geographicae 28B/1: 39-47.

PwC, Pricewaterhouse Coopers, 2011. Reports on major Polish cities - Szczecin. Warsaw.

Raport o stanie miasta Szczecin (Report on the state of Szczecin city), 2012. Szczecin. http://bip.um.szczecin. pl/UMSzczecinFiles/file/Raport_o_stanie_miasta_ SZCZECIN_2013.pdf.

Smalec A., Wachowicz P., 2009. Komunikacja i wdrażanie wartości marki miasta Szczecina (Communication and implementation of values of the city brand of Szczecin). Przestrzeń i Forma 19: 107-120.

Strategia Rozwoju Szczecina 2025 (Szczecin Development Strategy 2025), 2011. http://www.szczecin.eu/sites/default/files/strategia_rozwoju_szczecina_2025.pdf.

Tölle A., 2013a. Transnationalisation of development strategies in East-Central European cities. A survey of the shortlisted Polish European Capital of Culture candidate cities. European Urban and Regional Studies. Online First, DOI:10.1177/0969776413512845.

Tölle A., 2013b. National planning systems between convergence and incongruity: Implications for cross-border cooperation from the German-Polish perspective. European Planning Studies 21 (4): 615-630.

Węcławowicz G., 1996. Contemporary Poland. Space and society. Westview, Boulder.

Weichhart P., 2005. On paradigms and doctrines. The "Euroregio of Salzburg" as a bordered space. In: van Houtum H., Kramsch O., Zierhofer W. (eds), B/ordering Space. Ashgate, Aldershot \& Burlington: 93-108.

Zimnicka A., 2005. Przestrzenie publiczne miasta w dobie suburbanizacji - obszar metropolitalny Szczecina (Urban public space in the times of suburbanisation - the metropolitan area of Szczecin). Czasopismo Techniczne. Architektura 102 (9A): 395-401. 